\title{
PERAN BADAN USAHA MILIK DESA (BUMDESA) TERHADAP PENINGKATAN PENDAPATAN MASYARAKAT DESA KATUMBANGAN
}

\author{
Andi Sudarmin Aziz, Ririn Erisyam, Rahmah Muin
}

\author{
Hukum Ekonomi Syariah, Fakultas Agama Islam, Universitas Al Asyariah Mandar \\ erisyanririn@gmail.com,rahmah_muin@gmail.com sudarminazis@yahoo.co.id
}

\begin{abstract}
Abstrak
Penelitian ini bertujuan untuk : 1) mengetahui bagaimana peran BUMDesa Salosso dalam meningkatkan pendapatan masyarakat desa Katumbangan, 2) mengetahui apa faktor pendukung dan penghambat BUMDesa Salosso dalam meningkatkan pendapatan masyarakat ddesa Katumbangan. Teknik pengumpulan data berupa observasi (pengamatan langsung), wawancara (interview) dan dokumentasi berupa literatur yang mendukung. Implikasi dari Penelitian ini adalah: 1)BUMDesa Salosso perlu melakukan kegiatan pengenalan BUMDesa terhadap masyarakat secara merata agar masyarakat sadar akan pentingnya BUMDesa untuk kemajuan desa serta masyarakat, 2)BUMDesa Salosso sebauknya melakukan peminjaman barang terhadap masyarakat yang ingin berdagang, 3)BUMdesa Salosso sebaiknya mengganti jenis usaha toserba dengan jenis usaha lain, contohnya adalah air galon. Kata Kunci : BUMDesa, Peningkatan Pendapatan
\end{abstract}

\begin{abstract}
This study aims to: 1) find out how the role of BUMDesa Salosso in improving Katumbangan village income, 2) know what factors supporting and inhibiting BUMDesa Salosso in increasing the income of the people of Katumbangan village. Data collection techniques in the form observation (direct observation), interview (interview) and documentation in the form of supporting literature. The implications of this research are: 1) BUMDesa Salosso needs to do BUMDesa introduction activities towards the community equally so that the community is aware of the importance of BUMDesa for the progress of the village as well community, 2) BUMDesa Salosso should lend goods to people who want to trading, 3) BUMdesa Salosso should replace the type of convenience store business with another type of business, for example is gallon water.
\end{abstract} Keywords: BUMDesa, Income Increase 


\section{PENDAHULUAN}

Unit terkecil dari Negara yang terdekat dari masyarakat adalah desa dan menyentuh kebutuhan masyarakat secara langsung untuk disejahtrakan. Pendapat Undang-Undang Desa UU Nomor 6 Tahun 2014 Huruf abahwa desa memiliki hak tradisional dan hak latar belakang dalam mengurus dan mengatur kepentingan warga setempat dan berperan mewujudkan cita-cita kemerdekaan berdasarkan Undang-Undang Dasar Negara Republik Indonesia Tahun 1945 Dijelaskan pula pada pasal 1 bahwa desa adalah kepaduan masyarakat hukum yang mempunyai batas wilayah yang berkuasa untuk mengelola dan menangani urusan pemerintahan, keperluan masyarakat, hak asal mula, dan/atau hak tradisional dalam sistem pemerintahan negara kesatuan republik Indonesia yang diakui dan dihormati. ${ }^{1}$ Dalam pelaksanan fungsi marga dibutuhkan musyawarat desa atau forum permusyawaratan marga atau yang disebut dengan lain nama adalah badan yang melaksanakan peran pemerintahan yang wakil dari penduduk desa merupakan anggotanya berdasarkan wilayah keterwakilan dan ditetapkan menurut demokratis.

Oleh karena itu pemerintah menerapkan ancangan baru yang diharapkan sanggup menstimulus dan mendorong roda perekonomian di pedesaan, salah satu usaha yang dapat dilakukan adalah dengan mendorong gerak ekonomi desa melalui Badan Usaha Milik Desa (BUMDESA) yang mewadahi kewirausahaan desa yang dikembangkan oleh pemerintah maupun masyrakakat desa. ${ }^{2}$

Dalam upaya meningkatkan kesejahtraan masyarakat pada tahun 2014 pemerintah menetapkan tahun 2014 Undang-Undang Nomor 6 Pasal 6 mengenai Desa yang berbunyi Badan Usaha Milik Desa, yang kemudian diucap BUM Desa, adalah badan usaha yang seluruhnya atau dominan modalnya dimiliki oleh desa melewati pernyataan secara langsung yang bersumber dari kekayaan desa yang dipisahkandemi mengelola aset, jasa penyajian, dan usaha lainnya untuk seagung-agungnya kesejahtraan masyarakat desa. ${ }^{3}$

BUMDesa menggambarkan instrument perdagangan ekonomi dalam negeri melalui beraneka macam jenis potensi. Tujuan utama perdagangan potensi ini untuk meningkatkan kesejahtraan ekonomi warga desa melewati usaha ekonomi yang mereka kembangkan. Di samping itu, kehadiran BUMDesa juga memyerahkan kontribusi akan pengembangan sumber perolehan murni yang memungkinkan desa sanggup melaksanakan kesejahtraan rakyat secara optimal baik dari pembangunan ataupun pengembangan.

Tahun 2014 dengan diterbitkannya Undang-Undang Nomor 6 tentang desa, yang dinyatakan desa dapat mendirikan Badan Usaha Milik Desa yang di sebut BUMDesa sepertimana yang diamanatkan dalam Bab X. ${ }^{4}$ sesuai dengan kebutuhan dan potensi desa Pemerintah desa dapat mendirikan Badan Usaha Milik Desa desa dengan

\footnotetext{
${ }^{1}$ Undang-undang Nomor 6Tahun 2014 Tentang Desa

${ }^{2}$ Maria Rosa, Peran Badan Usaha Milik Desa (BUMDES) Pada Kesejahtraan Masyarakat Pedesaan Studi Pada Bumdes di Gunung Kidul Yogyakarta, MODUS VOL. 28 (2): 155-167, 2016

${ }^{3}$ Undang-Undang Nomor 6 Tahun 2014 Tentang Desa

${ }^{4}$ Undang-Undang No. 6 Tahun 2014 Tentang Desa
} 
harapan dapat meningkatkan pendapatan masyarakat dan desa. Demi tindak lanjut dari penerapan pendirian BUMDesa,Peraturan pelaksaan UU Nomor 6 tentang desa berdasakan Pasal 136 PP Nomor 43 Tahun 2015 , maka anggaranpada awal pendirian BUMDesa Salosso bermodalkan Rp. 88.535.400.Hal ini bertujuan untuk unit-unit usaha baru yang dikelola oleh BUMDesa Solosso dapat berkembang juga meningkatkan aset yang dimiliki. tidak lepas dari semua itu pada pendalaman kemampuan di mula berdiri dalam memutuskan unit operasional dialaskan atas sumber daya manusia dan sumber daya alam lagi tak kalah penting adalah sumber daya Tuhan selaku dasar pokok dalam usaha yang dikembangkan. Situasi ini dijadikan laksana dasar pengembangan usaha. ${ }^{5}$

BUMDesa Salosso telah berdiri kurang lebih 4 tahun.Pada tahun 2015 BUMDesa Salosso telah membuka usaha-usaha baru dan menyalurkan dananya untuk dijadikan modal kepada pengguna atau usaha bidang perdagangan yang sudah ada untuk dikembangkan dengan harapan pemerintah Indonesia dapat menaikkan pertambahan ekonomi masyarakat di pedesaan agar tingkat kemiskinan masyarakat berkurang.

Dari hasil pemantauan penulis mengenai upaya desa Katumbangan, permasalahan modal sering dialami masyarakat untuk Perdagangan sehingga masyarakat terhambat untuk dapat memenuhi kebutuhan sehari-hari.Penelitian ini untuk mengetahui apakah Badan Usaha Milik Desa yang sudah berdiri di Katumbangan beroperasi sesuai atas tujuan BUMDesa secara nyata, yaitu terbantunya masayarakat desa dalam pemenuhan kebutuhan mereka, maka lebih jauh penulis ingin mengetahui apakah BUMDesa ini memiliki peranan dalam pengembangan penghasilan desa dan masyarakat sehingga akan berdampak pada kesejahtraan rakyat yang terdapat di desa katumbangan. Selain itu juga penulis tertarik untuk memahami faktor-faktor pembantu dan kendala BUMDesa Salosso ketika memajukan perekonomian masyarakat desa katumbangan.

Berdasarkan latar belakang di atas maka penulis ingin meneliti dengan mengambil judul "Peran Badan Usaha Milik Desa (BUMDesa) terhadap Peningkatan Pendapatan Masyarakat Desa (Studi Kasus pada Badan Usaha Milik Desa (BUMDesa) Salosso di Desa Katumbangan Kecamatan Campalagian Kabupaten Polewali Mandar”.

Bersumber pada uraian motif kerangka masalah di atas, lalu yang menjadi fokus persoalan pada penelitian ini adalah:

1. Bagaimana peran BUMDesa Salosso dalam meningkatkan pendapatan masyarakat desa Katumbangan kecamatan Campalagian kabupaten Polewali Mandar?

2. Apa faktor pendukung dan penghambat BUMDesa Salosso dalam meningkatkan perndapatan masyarakat desa Katumbangan kecamatan Campalagian kabupaten Polewali Mandar?

\section{KAJIAN PUSTAKA}

\section{A. Otonomi Desa}

Otonomi desa mengggambarkan kedaulatan yang asli, bulat dan utuh serta bukan merupakan kontribusi dari pemerintah.melainkan pemerintah bertanggung jawab menghormati kedaulatan asli yang dimiliki bagi desa tersebut, sebagai kesatuan

\footnotetext{
${ }^{5}$ Latar Belakang AD-ART BUMDesa Salosso
} 
masyarakat hukum yang memiliki lapisan asli berlandaskan hak khusus, desa mampu melangsungkan perbuatan hukum, baik hukum terbuka, maupun hukum perdata, mempunyai kekayaan, harta benda serta boleh di tuntut dan menuntut di depan pengadilan. ${ }^{6}$

Otonomi desa pada era sekarang ini diatur oleh Undang-Undang Nomor 6 tahun 2014tentang desa juga kebijakan pemerintah Nomor 43 Tahun 2014 kebijakan penerapan Undang-Undang Nomor 6 Tahun 2014 tentang desa, dengan pemahaman bahwa otonomi desa melambangkan desentralisasi kewenangan dari pemerintah ke pemerintah desa dalam pelaksana pemerintahan. Dengan begitu pemerintah desa mengantongi urusanurusan yang sudah diserahkan oleh pemerintah dan menjadi tanggungan desa sepenuhnya. ${ }^{7}$ Otonomi desa menganut Prinsip otonomi yang disertai kewenangan mengelola serta membenahi kebutuhan masyarakat setempat berlandaskan asal usul dan adat istiadat.

\section{B. Pembangunan Desa dan Pemberdayaan Masyarakat}

Pendirian pedesaan sendiri sebenarnya difungsikan untuk menunjukkan sebuah gerakan yang di ambil dan gagasan untuk menaikkan hidup di area non-urban, perdesaan, dan desa-desa tertinggal. Dalam hal ini gerakan agraria mungkin akan dominan dan kegiatan perdagangan akan berkaitan dengan bidan primer, pembuatan konsumsi, dan bahan baku. Kepadatan penduduk di pedesaan masih tergolong rendah.Jarak setiap perumahan masih dipisahkan oleh tanah pertanian atau pekarangan yang cukup luas.Hal itu dikarenakan lokasi perdesaan masih meliputi lokasi yang cukup luas dan sebagai salah satu upaya pemerintah yaitu mengarahkan peningkatan dipertifikasi pertanian, perikanan, kehutanan, dan perdesaan selain itu, pemerintah juga telah mengoptimalkan pembangunan infrastruktur di perdesaan. ${ }^{8}$

Pemberdayaan masyarakat adalah kemampuan dan potensi yang dimiliki masyarakat di upayan untuk dtingkatkan, sehingga masyarakat dapat menumbukan cirri khas,derajat dan martabatnya secara maksimum untuk memperkuat dan mengembangkan diri secara bebas baik di bidang ekonomi, sosial, kepercayaan dan adat.

Dalam Islam, kerangka pemberdayaan telah Allah firmankan pada surah Al Jumu'ah ayat 10:

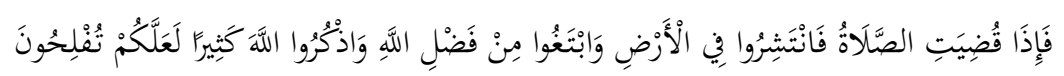

${ }^{6}$ Haw widjaja, Otonomi Desa(merupakan ototnomi yang asli, bulat dan utuh), (Jakarta;Rajawali Pers, 2012) hlm 165

${ }^{7}$ Undang-Undang Republik Indonesia Nomor 6 Tahun 2014.

${ }^{8}$ Fitriani L.h Membangun Desa Idaman(cet-1 Tahun 2011) hlm 3 dan 14 
Terjemahnya:

"Andaikan sudah pernah ditunaikan shalat, hingga bertebaranlah engkau di sisi bumi; dan carilah nikmat Allah dan ingatlah Allah banyak-banyak aga engkau beruntung. "(Q.S Al-Jumu'ah :10)

Ayat ini bertujuan untuk menyemangati manusia agar berupaya, mencari nafkah sehingga dapat keluar dari kemelaratan baik pada dirinya sendiri, kerabat dekatnya maupun warga di sekelilingnya. Ayat ini bermakna bahwa apabila shalat telah berakhir, kamu bebas bertebaran di bumi, memohon Allah SWT untuk menganugrahi karuniakarunia-nya dan mengingat Allah disegala waktu agar kamu meraih keselamatan.Dengan demikian,ayat ini dapat menjadi pondasi bagi BUMDesa selaku usaha desa yg bertujuan untuk meningkatkan kesejahtraan masyarakat.

\section{Badan Usaha Milik Desa (BUMDESA)}

Pada kebijakan Menteri Desa Nomor 4 tahun 2015 Bab II Pasal 2 berbunyi maksud pendirian BUMDesa selaku upaya mewadahi semua aktivitas di sektor ekonomi dan/atau penyajian umum yang dioperasikan oleh Desa dan/atau kolaborasi antar desa. ${ }^{9}$

Target dan manfaat Badan Usaha Milik Desa Pendirian BUMDesa bermaksud:

a. Perekonomian desa ditingkatkan.

b. Memaksimalkan asset Desa agar berguna untuk kemaslahatan Desa.

c. Pengelolaan potensi ekonomi Desa untuk meningkatkan usaha masyarakat.

d. Menumbuhkan konsep kolaborasi usaha antara desa dan/atau dengan golongan ketiga.

e. Membentuk kesempatan dan jaringan pasar yang menjunjung keperluan layanan terbuka warga.

f. Lapangan kerja yang dibuka.

g. Memajukan kesejahtraan masyarakat melewati permbetulan penyajian umum, perkembangan dan pemerataaan ekonomi desa; dan

h. Meninggikan pendapatan Asli Desa dan pendapatan masyarakat desa. ${ }^{10}$

Struktur kepengurusan organisasi pengelolaan BUMDesa terdiri atas:

a. Penasehat

b. Penerapan operasional dan

c. pengawas $^{11}$

\footnotetext{
${ }^{9}$ Peraturan Menteri Desa Pembangunan Daerah Tertinggal dan Trasmigrasi RI Nomor 4 Tahun 2015

${ }^{10}$ Peraturan menteri Desa Pembangunan Daerah Tertinggal dan Trasmigrasi RI Nomor 4Tahun 2015

${ }^{11}$ Peraturan Menteri Desa Pembangunan Daerah Tertinggal dan Trasmigrasi RI Bagian Kedua Organisasi Pegelolaan BUMDesa Pasal 10
} 


\section{Kesejahtraan Masyarakat}

Kesejahtraan adalah terlepasnya seseorang dari jeratan kesulitan, ketidaktahuan dan rasa khawatir sehingga dia mendapatkan kehidupan yang aman dan sejahtera secara jasmani maupun rohani. ${ }^{12}$ Islam menjelaskan bahwa kesejahtraan tidak sekedar berkaitan dengan terpenuhinya materi semata-mata, tetapi juga terpenuhinya kebutuhan spiritual. ${ }^{13}$ Sebagaimana dijelaskan dalam Qs. Al-Nahl: 97

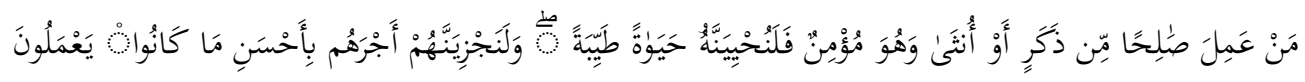

Terjemahnya:

"Barangsiapa yang menunaikan amal saleh, baik pria maupun wanita dalam Kondisi beriman, bahwa sebenarnya akan Kami berikan kepadanya kehidupan yang berfaedah[839] dan Sebenarnya akan Kami beri ganjaran kepada mereka dengan pahala yang makin baik dari apa yang sudah mereka lakukan. '(Q.S AlNahl: 97)

\section{E. Kerangaka Pemikiran}

Spesifikasi dalam penelitian ini adalah menganalisis pengaruhBUMDesa terhadap pengembangan ekonomi desa Katumbangan kecamatan Campalagian kabupaten Polewali Mandar.berlandaskan gagasan tersebut harus diteliti pengelolaan BUMDesa yang sudah berdiri di desa Katumbangan kecamatan Campalagian, denganmenganalisis secara deskripsi responsif, partisipatif, emansipatif,terbuka,akuntabel, sustainabel. Tujuan akhir penelitian ini adalah bakal menaikkan penghasilan murni dari desa dan pengembangan ekonomi rakyat desa Katumbangan kecamatan Campalagian yang memilikiBUMDesa dengan mengupas penghasilan masyarakat dan penedotan tenagakerja rakyat desa dengan adanya BUMDesa, sehingga pengembanganekonomi rakyat desa Katumbangan kecamatan Campalagian kabupaten Polewali Mandar dapat tercapai dengan meningkatnya ekonomi masyarakat di desa Katumbangan kecamatan Campalagian kabupaten Polewali Mandar.

\section{METODE PENELITIAN}

Penelitian ini ialah percobaan kualitatif deskriptif. Penulis melaksanakan penelitian di BUMDesa Salosso desa Katumbangan kecamatan Campalagian kabupaten Polewali Mandar.Penelitian penulis yaitu peran BUMDesa (Badan Usaha Milik Desa) Terhadap Pelonjakan Penghasilan warga (Riset masalah di Desa Katumbangan Kecamatan Campalagian Kabupaten Polewali Mandar).

\footnotetext{
${ }^{12}$ Amirus sodiq,Konsep Kesejahtraan Dalam Islam,EQUILIBRIUM, Vol3, No. 2,Desember 2015.

${ }^{13}$ Fathurahman Djamil,Hukum Ekonomi Islam, 9Jakarta: Sinar Grafika, 2013) hlm 17
} 
Ancangan penelitian yang dikenakan adalah pendekatan kualitatif. Data yang diselesaikan lebih mencapai bentuk kata-kata atau gambar. Adapun hasil penelitian tercatat berisi kutipan-kutipan untuk mempersiapkan bukti presentasi. Datatersebut mencakup transkrip interviu, catatan lapangan, pengambilan gambar, videotape, datapribadi, memo, dan rekaman-rekaman resmi lainnya. ${ }^{14}$

Data primer adalah data observasi yang didapat secara telak dari sumber aslinya yang berwujud Tanya jawab, jajak pendapat dari perorangan atau kumpulan (orang) ataupun hasil observasi dari suatu obyek, peristiwa atau hasil percobaan (benda). Dengan kata lain, observasi membutuhkan pengumpulan data dengancara merespon interogasi riset (metode survei) atau penyelidikan barang (metode observasi).

Keunggulan dari data primer adalah data makin memperlihatkan bukti berdasarkan dengan apa yang dilihat serta didengar spontan oleh penyelidik sehingga unsur-unsur kecurangan dari sumber yang aneh dapat dihindari, sedangkan kelemahan dari data primer adalah membutuhkan waktu yang relatif lama juga beban yang di keluarkan relatif lumayan banyak.

Data sekunder adalah data pendalaman yang berasal dari saana perantara atau secara tidak langsung yang berbentuk buku, tulisan, bukti yang telah ada atau arsip baik yang dipublikasikan maupun yang bukan dipublikasikan selaku umum dengan kata lain, penyelidikan membutuhkan pengumpulan data dengan caramengunjungi taman pustaka, pusat kajian, pusat arsip atau membaca banyak buku yang berkaitan dengan observasi. Dalam pengumpulan data, menggunakan sistem observasi, Tanya jawab mendalam, dan pengambilan gambar.

Observasi digunakan untuk meperoleh data hasil pangawasan. Pengawasan biasa dilakukan terhadap objek benda, keadaan, kondisi, situasi, aktivitas, proses, atau penampilan tingkah laku seseorang. ${ }^{15}$

Wawancara mendalam digunakan sebagai proses pengumpulan data apabila peneliti ingin studi permulaan untuk menemukan permasalahan yang harus diteliti. ${ }^{16}$

Dokumentasi, yaitu benda-benda yang tercatat atau dicetak untuk digunakan sebagai suatu tulisan atau bukti.Dalam hal ini pencatatan mengumpulkan data melalui keterangan secara tertulis yang merupakan dokumen-dokumen yang ada hubungannya dengan data yang dibutuhkan dalam penelitian.

Dalam penelitian kualitatif, yang menjadi instrumen atau alat penelitian adalah peneliti itu sendiri. Peneliti sebagain human instrument yang berfungsi menetapkan fokus penelitian, pemilihan informan sebagai sumber data menilai kualitas data, melakukan pengumpulan data, analisis data, menafsirkan dan membuat kesimpulan atas temuannya. ${ }^{17}$

${ }^{14}$ Emzir, Metodologi Penelitian Kualitatif Analisis Data, (Ed.1, Cet. 4; Jakarta: Rajawali Pers, 2014) h, 3.

${ }^{15}$ Sanapiah Faisal, Format-format Penelitian Sosial (Cet. V; Jakarta: PT Raja Grafindo Persada, 2001), h. 135

${ }^{16}$ Sugiyono, Metode Penelitian Pendidikan Pendekatan Kuantitatif, Kualitatif dan R\&D, h.lm 80 dan 194.

\footnotetext{
${ }^{17}$ Abuddin Nata, Metodologi Studi Islam (Cet. XVII; Jakarta: Raja Grafindo Persada, 2010), h. 306.
} 
Analisis data dalam penelitian kualitatif, dilakukan pada saat pengumpulan data berlangsung untuk mengetahui kendala-kendala yang ada selama pengumpulan data dalam periode tertentu.Analisis data ini dilakukan secara terus menerus sampai tuntas.

Analisis data model Miles dan Huberman dilakukan melalui 3 tahap, yaitu:

\section{Reduksi Data}

Reduksi data berarti merangkum, memilih hal yang pokok, memfokuskan pada hal yang penting, dicari pola dan temanya. Reduksi data merupakan proses pemilihan, pemutusan perhatian melalui penyederhanaan, pengabstrakan, dan transformasi data "kasar" yang mencul dari catatan-catatan tertulis di lapangan.

2. Penyajian Data

Penyajian data berarti mendisplay/menyajikan data dalam bentuk uraian singkat, bagan, hubungan antar kategori.Penyajian data yang sering digunakan dalam penelitian kualitatif adalah bersifat naratif. Ini dimaksudkan untuk memahami apa yang terjadi, merencanakan kerja selanjutnya berdasarkan apa yang dipahami.

3. Penarikan Kesimpulan dan Verifikasi

Penarikan kesimpulan dalam penelitian mungkin dapat menjawab rumusan masalah, karena rumusan masalah dalam penelitian kualitatif masih bersifat sementara dan berkembang setelah peneliti berada dilapangan.Kesimpulan penelitian kualitatif merupakan temuan baru yang disajikan berupa deskripsi atau gambaran yang awalnya belum jelas mejadi jelas dan dapat berupa hubungan kausal/interaktif dan hipotesis/teori.Penarikan kesimpulan dan verivikasi dilakukan setelah dari lapangan. ${ }^{18}$ Tahap ini merupakan penarikan kesimpulan dari data yang telah ada sebagai hasil dari penelitian.

\section{HASIL PENELITIAN}

\section{A. Peran BUMDesa Salosso dalam Meningkatkan Pendapatan Masyarakat.}

Dari hasil pengamatan yang dilakukan bagi penyusun diketahui maka BUMDesa Salosso pertama kali berjalan di tahun 2015, BUMDesa Salosso memiliki prinsip-prinsip dasar pengelolaan yang transparan. Pengelolaan kegiatan BUMDesa Salosso harus sesuai dengan peraturan yang berlaku agar dapat dipertanggung jawabkan sehingga pengelolaan dan kegiatan dapat memberikan hasil serta manfaat terhadap masyarakat desa katumbangan secaramerata, maka dari itu masyarakat dan pengurus sangat diharapkaan aktif dalam proses kegiatan.

Wawancara pertama dilakukan oleh penulis dengan pengelola BUMDesa Salosso yang menjabat sebagai ketua BUMDesa Salossobahwa dalam pengurusan BUMDesa Salosso terdapat beberapa kendala berdirinya BUMDesa Salosso seperti beberapa usaha yang tidak berjalan sesuai rencana dan tahapan pendirian program usaha BUMDesa Salosso, pertnyaan peneliti yang dipaparkan kepada ketua bumdesa salosso yaitu ini bumdesta kak bumdes salosso berdiri tahun berapa? Memang itu bumdes salosso yang pertama yang anumya memang programnya itu campuran?

${ }^{18}$ Sugeng Pujileksono, Metode Penelitian Komunikasi Kualitatif(malang: Intrans Publishung, 2015), h. 152 
"BUMDesa Salosso pertama kali berdiri pada tahun 2015, Dana awal BUMDesa Salosso bersumber dari dana desa yang tiap tahunnya dialokasikan untuk BUMDesa Salosso serta proposal yang diajukan atau tergantung dari barang serta kebutuhan yang diperlukan danbelum ada bantuan dari pemerintah kabupaten, provinsi maupun pihak lain yang menyuntikan dana ataupun barang ke BUMDesa Salosso dan memulai program usaha dengan menjual jasa yaitu sewa molen atau alat mixer semen,di lanjut usaha yang kedua yaitu jasa tempat pembayaran listrik dan penyediaan pupuk awalnya dilakukan usaha tiga macam secara bertahap, dan BUMDesa Salosso sempat menambahkan jenis usaha yaitu pembibitan kambing namun ssudah di validkan atau di nonaktifkan dikarenakan kambing-kambing yang di ternakaan oleh pengurus mengalami kematian satu persatu dan akhirnya progam pembibitan kambing di hapuskan dalam daftar program usaha BUMDesa Salossopada tahun 2017.BUMDesa Salosso mendirikan jenis usaha baru yaitu TOSERBA (toko serba ada) pada tahun 2017 penggantian usaha pembibitan kambing, dan pada tahun yang sama di tahun 2017 bulan desember BUMDesa Salosso juga mendirikan usaha baru yaitu percetakan seperti fotocopy, jilid, print out, atk, dll, dan dirangkum dalam satu lokasi atau lebih tepatnya di samping kantor Desa Katumbangan ",19

Setelah penulismengetahui jawaban pengelola BUMDesa Salosso bahwa sejak berdirinya BUMDesa Salosso pada tahun 2015 hingga saat ini ada 6 jenis usaha yang telah di programkan namun salah satu programnya di validkan dan tahapan-tahapan berdirinya program usaha dari tahun 2015 hingga saat ini.

Kemudian penulis mempertanyakan selama berdiri bumdes salosso apa- apa saja anunya kak masalah yang didapat selma berdirinya?

"Pada awal berdirinya BUMDesa Salosso memiliki kendala dalam mensosialisasikan atau memperkenalkan BUMDesa Salosso kepada masyarakat Desa Katumbangan karna tidak semua masyarakat Desa Katumbangan mengetahui adanya BUMDesa Salosso terlebih pada dusun yang jauh dari BUMDesa Salosso dan sebenarnya pihak pengelola BUMDesa salosso memiliki bnyak rencana untuk mengembangkan BUMDesa Salosso cuman terkendala biaya dan pihak pemerintah desa apakah proposal yang diajukan pihak pegelola di acc atau tidak, karna BUMDesa Salosso bergantung dari desa karna pendanaan keseluruhan bersumber dari desa, pengelola BUMDesa Salosso yang pertama adalah aparat desa namun sejak tahun 2017 ada aturan baru bahwa perangkat desa tidak bisa merangkap maka dari tu dagantilah pengurus baru yang berjumlah 3 orang. ",20

Setelah kembali mendengarkan pernyataan pengelola BUMDesa Salosso bahwa pihak pengelola memiliki kendala dalam pengenalan BUMDesa Salosso serta keinginan

\footnotetext{
${ }^{19}$ Hasil wawancara Nasaruddin, selaku ketua bemdes Salosso.04 September 2019

${ }^{20}$ Hasil wawancara Nasaruddin, selaku ketua bemdes Salosso.04 September 2019
} 
pengelola untuk mengembangkan usaha BUMDesa Salosso yang terhalang oleh terbatasnya anggaran dana dari pihak desa.

Kemudian peneliti mempertanyakan tentang bagaimana usaha pengelola BUMDesa Salosso dalam mengembangkan programnya agar bermanfaat bagi masyarakat desa katumbangan.

"Perkembangan BUMDesa Salosso sejak berdiri sampai sekarang belum terlalu Nampak baik untuk desa maupun masyarakat karna pada awal berdirinya BUMDesa Salosso pihak pengelola lebih mengutamakan inventaris barang atau persediaan barang, sejauh ini memang BUMDesa Salosso telah memperoleh sedikit keuntungan namun belum cukup untuk menutupi biaya inventaris barang, jadi belum ada yang masuk ke kas desa berupa PAD (pendapatan asli desa)Program yang di kembankan BUMDesa Salosso salah satunya adalah TOSERBA(toko serba ada) yang melayani secara grosir agar masyarakat Desa Katumbangan lebih dekat untuk berbelanja dan tidak lagi ke pasar campalagian atau wonomulyo untuk mencari harga barang yang lebih murah, apa lagi program ini di peruntukan oleh masyarakat yang memiliki usaha campuran yang memiliki keterbatasan modal dan kendaran, jadi selain murah Toserba juga lebih gampang dijangkau oleh masyarakat desa katumbangan". ${ }^{21}$

Program BUMDesa Salosso merupakan program yang mengutamakan kepentingan masyarakat desa katumbangan dalam hal peningkatan kesejahtraan masyarakat atau taraf hidup masyarakat. Pelaksanaan BUMDesa Salosso yang di kelola oleh pengurus, masyarakat dan pihak-pihak lain yang ikut serta dalam pengurusan BUMdesa yang bertujuan untuk meningkatkan pendapatan masyarakat desa katumbangan, maka di bentuklah beberapa program BUMDesa untuk menunjang perkembangan desa katumbangan.

Program utama BUMDesa Salosso adalah TOSERBA (Toko Serba Ada) yang berfungsi untuk memberikan kemudahan kepada masyarakat untuk menjalankan usaha campuran agar lebih dekat dan lebih hemat, di adakan program toserba karena letak desa katumbangan yang jauh dari kecamatan campalagian hal ini jg mendorong pengurus BUMDesa untuk mengembangkan program toserba untuk memudahkan masyarakat berwirausaha, adapun program lain BUMDesa Salosso yaitu penyedian pupuk bagi petani dimana masyarakat desa katumbangan sebagian besar berprofesi sebagai petani, terlihat dari 8 dusun di katumbangan semuanya mempunyai lahan bertani hal ini yang mendorong pengelola BUMDesa Salosso untuk mengadakan program pengadaan pupuk.

program ini berfungsi untuk memudahkan masyarakat dalam menjangkau pupuk lebih dekat dilihat dari jauhnya pasar yang ada di campalagian dan wonomulyo, pengurus BUMdesa Salosso mengadakan program ini agar hasil petani di desa katumbangan dapat meningkat, dapat dilihat dari program pemerintah tentang pengairan sawah yang mendorong petani untuk melakukan panen tiga kali setahun hal ini yang mendasari pengelola BUMDesa Salosso untuk mengembangkan program pengadaan

\footnotetext{
${ }^{21}$ Hasil wawancara Nasaruddin, selaku ketua bemdes Salosso.04 September 2019
} 
pupuk.Peningkatan kesejahtraan masyarakat sudah terlihat meskipun belum maksimal karena ke enam program BUMDesa Salosso yang ada sudah mendekati harapan dan pemerintah desa katumbangan bersama pengelola BUMDesa Salosso terus mengoptimalkan program BUMDesa Salosso.

\section{B. Faktor Pendukung dan Penghambat BUMDesa Salosso dalam Meningkatkan Pendapatan Masyarakat Desa Katumbangan Kecamatan Campalagian Kabupaten Polewali}

Program usaha di BUMDesa Salosso belum berkembang dengan baik akan tetapi pemerintah desa bersama pengelola BUMDesa Salosso berusaha mengoptimalkan kinerja unit-unit tersebut sehingga dapat tercapai tujuan BUMDesa Salosso, salah satu cara BUMDesa Salosso adalah penyediaan barang di Toserba dan penyedian pupuk untuk masyarakat yang berprofesi sebagai petani.

Masyarakat awam yang belum mengetahui tentang BUMDesa apalagi kurangnya sosialisasi tentang BUMDesa dan Perkenalan program usaha-usaha yang memang masyarakat anggap hanya toko biasa. Yang membuat program yangdidirikan mendapatkan hambatan.Sebagian masyarakat menganggap kemunculan program usaha BUMDesa Salosso dapat mematikan usaha yang sama yang dimiliki masyarakat dapat mengalami kegagalan seperti penjelasan pada saat wawancara yang di lakukan peneliti terhadap masyarakat dusun katumbangan bernama firman yang berpropesi sebagai penjual campuran, peneliti bertanya kita tau bumdes? apakah Ada maanfaat Bumdes yg kita rasakan selama berdiri?

"BUMDesa termasuk usaha desa yang mempunyai program jual campuran, memang ada sedikit manfaat yang dirasakan konsumen/warga justru yang merasa tersaingi adalah masyarakatnya terutama penjual campuran yang berada dekat dari BUMDesa, masyarakat merasa tersaingi bahkan ada yang tutup, manfaat BUMDesa bisa dibilang ada bisa juga tidak ada ${ }^{322}$

Dampak yang dirasakan masyarakat khususnya dusun katumbangan yang memiliki usaha yang sama yang membuat masyarakat merasa tersaingi bahkan gulung tikar, dampak ini sangat dirasakan masyarakat terlebih masyarakat sekitar BUMDesa Salosso di dusun katumbangan.

Peningkatan kesejahtraan masyarakat yang di harapkan pemerintah beserta pengelola BUMDesa Salosso jelasnya belum berdampak, diketahui dari hasil pemantauan dan Tanya jawab terhadap masyarakat yang masih kurang mengetahui adanya keberadaan BUMDesa dan kurang tahu fungsi sebenarnya BUMDesa Salosso. kurangnya sosialisasi dari pihak pengelola kepada masyarakat dan faktor masyarakat yang kurang peduli dan masa bodoh terhadap program-program yang berkaitan dengan pemerintah desa. Seperti wawancara peneliti terhadap warga dusun kampung masigi salah satu dusun yang dekat dari bumdesa salosso. Kita tahu bumdes? Tidak ada pernah sosialisasinya desakah tentang bumdes?

\footnotetext{
${ }^{22}$ Hasil wawancara Firman, selaku warga dusun Katumbangan. 29 September 2019
} 
"Biasa juga dengar itu Tapi Tidak ku paham apa itu, sama skli tidak ku tahu, kalau untuk saya tidak tahu,"23

Kurangnya pendekataan terhadap masyarakat yang menimbulkan pengaruh besar terhadap eksistensi BUMDesa Salosso karena peran masyarakat sangat di butuhkan dalam meningkatkan unit usaha BUMDesa Salosso. Karena di desa katumbangan banyak memiliki perbedaan di antara masyarakat desa baik dari segi pendidikan, usia dan mata pencaharian. Pertnyaan peneliti kepada arga dusun katumbangan, Pernahki tahu tentang bumdes, atau pernahki ke bumdes?

"jarang tahu tentang bumdes, tapi pernah ji kesana tpi jarang, mungkin pernah ji sosialisasi tpi dirumahnya pak dusun cuman jauh rumahnya pak dusun dari sini. $" 24$

Peran pengurus BUMDesa Salosso sangat penting dalam menjalin kerjasama antara masyarakat desa katumbangan, pengurus harus selalu turun langsung ke masyarakat untuk mengajak dan mendorong masyarakat desa katumbangan untuk ikut aktif dalam pembangunan BUMDesa Salosso, karena tanpa adanya kerjasama antara pengurus dan masyarakat maka tujuan BUMdesa Salosso dalam meningkatkan kesejahtraan masyarakat desa katumbangan tak akan terwujud. Pertanyaan peneliti kepada warga dusun berampa sekaligus kepala dusun berampa dan pengawas BUMDesa salosso, kan kita ini sebagai kepala dusunnya berampa pengetahuanta tentang bumdes, atau pernahki ka aktif disana di bumdes? Atau adakah responnya masyarakat sini tentang bumdes?

"Kalau warga disini jarang ke campalagian, karna di berampa ada tiga grosir,biasa juga terbuka bisa tidak, kurang aktif disana karena saya juga disana sebagai pengawas sama pak baharuddin, mungkin nanti mau di tambah karna saya kesana sekali seminggu setahuku semua keuntungannya masuk ke kas $\operatorname{desa}^{, 25}$

Dilihat dari hasil wawancara penulis, kurangnya respon masyarakat terhadap BUMDesa Salosso terlebih jenis program usaha toserba yang diterapkan BUMDesa Salosso menyamai usaha milik masyarakat, hal ini dapat mengurangi minat masyarakat ke BUMDesa Salosso meskipun jarak antara BUMDesa dan dusun berampa berjauhan tpi hal ini dapat mempengaruhi usaha BUMDesa ditambah tidak menentunya BUMDesa Salosso beroperasi, hal ini dapat menghambat BUMDesa Salosso dalam meningkatkan Pendapatan masyarakat desa Katumbangan.

Tujuan berdirinya BUMDesa Salosso adalah meningkatkan ekonomi masyarakat desa katumbangan dan berdirinya organisasi ini dibutuhkan kerja sama yang baik dari pengelola BUMDesa Salosso dan masyarakat katumbangan, berdasarkan hasil wawancara

\footnotetext{
${ }^{23}$ Hasil wawancara Melia, selaku warga dusun kampung masigi.29 September 2019

${ }^{24}$ Hasil wawancara Rahmatia, selaku warga Dusun Barasse. 29 September 2019

${ }^{25}$ Hasil wawancara handarullah, selaku kepala dusun berampa dan pengawas BUMDesa
} Salosso, 29 September 2019 
peneliti diketahui berikut faktor-faktor pendukung dan penghambat BUMDesa Salosso dalam mensejahterakan masyarakat melalui program-programnya:

1. Dapat menyediakan layanan kepada masyarakat untuk mempermudah masyarakat yang berprofesi sebagai pedagang

2. Menyediakan keperluan petani untuk keperluan tanamannya

3. Usaha BUMDesa Salosso sesuai dengan kondisi ekonomi dan sosial masyarakat

Selain faktor pendukung yang sifatnya turut mendorong atau menunjang perkembangan BUMDesa Salosso adapun faktor penghambat yang bersifat menghambat atau bahkan menghalangi usaha BUMDesa Salosso:

1. Usaha yang dijalankan BUMDesa Salosso tidak semuanya pro terhadap masyarakat.

2. Jasa BUMDesa Salosso kurang efektif terhadap petani di desa katumbangan

3. Kurangnya empati masyarakat terhadap usaha BUMDesa Salosso

\section{KESIMPULAN}

1. Strategi yang di lakukan pihak pengelola BUMDesa Salosso sudah cukup baik, karena pihak BUMDesa telah melakukan tahapan identifikasi masalah, dimana masalah masyarakat yang mengalami kesulitan dalam pemenuhan kebutuhan berbelanja yang terkhusus bagi warga yang berprofesi sebagai penjual campuran, dimana menurut pemerintah desa serta pihak pengelola bahwa usaha yang tepat adalah usaha TOSERBA (toko serba ada). Serta unit usaha lain BUMDesa Salosso adalah pengadaan pupuk yang dinilai sangat strategis untuk unit usaha BUMDesa Salosso dimana wilayah Katumbangan adalah sebagian besar adalah ladan sawah dan bnyaknya masyarakat yang berprofesi sebagai petani, maka dengan usaha ini dapat membantu masyarakat dalam hal penyedian pupuk karena wilayah desa katumbangan berada jauh dari pasar campalagian serta pasar wonomulyo.

2. Faktor pendukung dan penghambat BUMDesa Salosso dalam meningkatkan pendapatan masyarakat Desa Katumbangan Kecamatan campalagian Kabupaten polewali.

a. Faktor pendukung

Unit-unit usaha yang di kelola BUMDesa Salosso di anggap sangat tepat karena keadaan masyarakat desa katumbangan yang mengalami kesulitan dalam pemenuhan kebutuhan terkhusus bagi masyarakat yang berprofesi sebagai pedagang campuran dimana faktor jarak yang jauh dari pasar membuat pengurus BUMDesa Salosso mengembangkan usaha Toserba, serta pengadaan pupuk bagi petani yang dimana masyarakat desa katumbangan sebagian besar berprofesi sebagai petani. ${ }^{26}$

b. Faktor penghambat

Sebagian masyarakat desa Katumbangan yang berada di dusun katumbangan tepat di wilayah BUMdesa Salosso berdiri menganggap bahwa unit

\footnotetext{
${ }^{26}$ AD-ART BUMDesa Salosso
} 
usaha BUMdesa Salosso dapat menyaingi usaha warga sekitar dampak ini sangat dirasakan warga yang memiliki jenis usaha yang sama, ${ }^{27}$ serta kurangnya sosialisasi tentang BUMDesa dari pihak pemerintah desa katumbangan serta pihak pengelola BUMDesa Salosso kepada masyarakat yang mengakibatkan kurangnya partisipasi atau dukungan masyarakat untuk perkembangan BUMDesa Salosso.

\section{DAFTAR PUSTAKA}

Arikunto, Suharsimi. Prosedur Penelitian Suatu Pendekatan Praktik. Cet.14.Jakarta :Rineka Cipta. 2010.

Al Qur'an dan Terjemahnya

Badrudin, Rudi. Ekonomi Otonomi Daerah.Yogyakarta: UPP STIM YKPN. 2012.

Djamil, Fathurahman. Hukum Ekonomi Islam, Jakarta: Sinar Grafika, 2013.

Emzir.Metodologi Penelitian Kualitatif Analisis Data.Ed.1, Cet. 4. Jakarta: Rajawali Pers. 2014.

Faisal, Sanapiah.Format-format Penelitian Sosial.Cet. V. Jakarta: PT Raja Grafindo Persada. 2001.

Fitriani L.h.Membangun Desa Idaman.Cet-1. 2011.

Haw, Widjaja.Otonomi Desa (merupakan ototnomi yang asli, bulat dan utuh).Jakarta;Rajawali Pers. 2012.

https://www.bacaanmadani.com diakses pada tanggal 25 oktober 2019

Kamaroesid, Herry.Tata Cara Pendirian dan Pengelolaan BUMDES.Jakarta: Mitra Wacana media.

Latar Belakang AD-ART BUMDesa Salosso.

Mashuri Maschab.Politik Pemerintahan Desa Di Indonesia.Yokyakarta:PolGov.Desember 2013.

Nata, Abuddin. Metodologi Studi Islam.Cet. XVII; Jakarta: Raja Grafindo Persada, 2010.

Peraturan Menteri Desa Pembangunan Daerah Tertinggal dan Trasmigrasi RI Nomor 4 Tahun 2015.

Peraturan Menteri Desa Pembangunan Daerah Tertinggal dan Trasmigrasi RI Bagian Kedua Organisasi Pegelolaan BUMDesa Pasal 10.

Purwana, Agung Eka.Kesejahtraan Dalam Perspektif Ekonomi Islam.Justitia Islamica. Vol. 11/Jan,-juni. 2014.

Rosa, Maria.Peran Badan Usaha Milik Desa (BUMDES) Pada Kesejahtraan Masyarakat Pedesaan Studi Pada Bumdes di Gunung Kidul Yogyakarta, MODUS VOL. 28 (2): 155-167. 2016.

Sodiq,Amirus. Konsep Kesejahtraan Dalam Islam,EQUILIBRIUM. Vol3. No. 2. Desmber 2015.

Sugeng, Pujileksono.Metode Penelitian Komunikasi Kualitatif.Malang: Intrans Publishung. 2015.

\footnotetext{
${ }^{27}$ Hasil wawancara penulis terhadap warga Desa Katumbangan
} 
Sugiyono, Metode Penelitian Pendidikan Pendekatan Kuantitatif, Kualitatif dan R\&D. Undang-Undang Nomor 6 Tahun 2014 Tentang Desa.

Undang-Undang No. 11 Tahun 2019 Tentang Kesejahtraan Sosial.

https://www.jogloabang.com (Tata Cara Mendirikan BUMDES).

https://www.jogloabang.com

Prioritas Penggunaan Dana Desa Tahun 2019, Permen Desa PDTT 16 tahun 2018. 